\title{
Effect of Growth Regulators on Micropropagation, Callus Induction and Callus Flavonoid Content of Rumex pictus Forssk
}

\author{
Nadia Mohamed El-Shafey ${ }^{\#}$, Mona Sayed, Enas Shabaan Ahmed, Ola Hammouda \\ and Salah El-Din Ali Khodary \\ Department of Botany and Microbiology, Faculty of Science, Beni-Suef University, \\ Beni-Suef, Egypt.
}

\begin{abstract}
$\mathbf{T}$ HE CURRENT study investigates the effect of growth regulators on micropropagation, callus induction and callus flavonoid content of Rumex pictus Forssk; an endangered medicinal plant. Various combinations of kintin (KIN), 6-benzylaminopurine (BAP), Thidiazuron (TDZ) and indole-3-butyric acid (IBA) were used for micropropagation from shoot tip explants. Murashige and Skoog (MS) medium containing $2 \mathrm{mg} \mathrm{L}^{-1} \mathrm{BAP}$ was the best for micropropagation where shoot formation frequency was $70 \%$ with 12.6 shoots/explant. The highest root formation frequency resulted on half-strength MS medium fortified with $2 \mathrm{mg} \mathrm{L}^{-1}$ naphthalene acetic acid (NAA) or $1 \mathrm{mg} \mathrm{L}^{-1}$ IBA. One $\mathrm{mg} \mathrm{L}^{-1}$ 2,4-dichlorophenoxyacetic acid $(2,4-\mathrm{D})$ combined with $0.4 \mathrm{mg} \mathrm{L}^{-1} \mathrm{BAP}$ induced the highest callus mass production from the investigated explants, particularly $1^{\text {st }}$ foliage leaf that was the best explant for callus induction and proliferation. The accumulation of flavonoids in callus was diminished by BAP but enhanced by increasing 2,4-D concentration in culture medium. To our knowledge, this is the first report of micropropagation and callus induction of this endangered medicinal plant which will help in its rapid mass production, conservation and in vitro production of secondary metabolites.
\end{abstract}

Keywords: Auxins, Callus, Cytokinins, Dock, Flavonoids, Shoot induction.

\section{Introduction}

The genus Rumex belongs to family Polygonaceae. Many species of Rumex have shown a broad spectrum antimicrobial and antioxidant activity due to their phytoconstituents such as flavonoids, anthraquinones and terpenoids, which give the species potentiality to be used in folk medicine. Moreover, important bioactive substances such as vitexin, isovitexin, orientin, isorientin, emodin and chrysophanol were isolated from some of Rumex species (Batanouny et al., 1999 and Sayed et al., 2017). Rumex pictus Forssk is a winter annual herb that is commonly known as dock. It is used in folk medicine as sedative, spasmogenic and antimicrobial (Mossa et al., 2000). Batanouny et al. (1999) considered $R$. pictus as an endangered medicinal plant in Egypt. This species was also reported as endemic and rare in northern and eastern deep sand areas in Saudi Arabia (Rahman et al., 2004).
Plant tissue culture is considered an alternative method to the conventional propagation of plants. In vitro culture and micropropagation as biotechnological techniques play an important role in ex situ conservation of the endangered medicinal plants (Goyal et al., 2014; Mahendran \& Narmatha, 2014 and Manole-Paunescu, 2014). Micropropagation provides all the year-round disease free plantlets production and rapid mass cloning of genotypes. In addition, it is an efficient mean of germplasm exchange, storage and maintenance. Micropropagation via shoot tips and stem meristems has been applied on rare and endangered medicinal plants like Polygonum hydropiper, $R$. vesicarius, Hypericum gaitii and Rheum emodi (Hasan \& Sikdar, 2010; Abo ElSoud et al., 2011; Swain et al., 2016 and Tabin et al., 2017) due to preserving the genetic integrity of the propagated plants. Extensive studies investigated the utilization of plant cell cultures for the production of plant metabolites with pharmacological activities (Matkowski, 2008).

"Corresponding author emails: nadia69shafey@yahoo.com; nadia.elshafey@science.bsu.edu.eg

Tel.: +201014243923, Fax: 002-082-2334551

DOI: $10.21608 /$ ejbo.2019.4873.1202

Edited by: Prof. Dr. Wedad Kasim, Faculty of Science, Tanta University, Tanta, Egypt.

C2019 National Information and Documentation Center (NIDOC) 
Secondary metabolites production via callus culture has advantage over their production from the intact plants, since the in vitro production is running under controlled conditions, independently from climatic and seasonal factors and provides a non-depleted and reliable source of natural products.

A main factor that masters the growth and success of the in vitro plant culture is growth regulators; auxins and cytokinins. The cytokinin, 6-benzylaminopurine (BAP), was found to induce in vitro regeneration of medicinal plants either alone (Al Khateeb et al., 2017) or when it was combined with auxins such as IBA (Tabin et al., 2017), NAA (Swain et al., 2016) or IAA; indole-3-acetic acid (Moharami et al., 2014 and Ślesak et al., 2014). Moreover, the involvement of cytokinins in callus culture media and their contribution in callus induction and proliferation are well established. Flavonoids are one of the largest groups of secondary metabolites that recently have been the subject of considerable scientific and therapeutic interest due to their proven ability to scavenge reactive oxygen species (ROS) in general (Matkowski, 2008). Plant growth regulators were found to affect the accumulation of flavonoids in cell culture (Murthy et al., 2014; Ji et al., 2015 and El-Shafey et al., 2016). The significant role of growth regulators on the biosynthesis of flavonoids is well documented, although it is not yet known how they act on the biosynthetic pathways (Jamwal et al., 2018). Combination and concentration of the applied auxin and cytokinine were reported to strongly influence the biosynthesis and accumulation of flavonoids in the cultured plant cell (Bota \& Deliu, 2015). Plant tissue culture techniques have been applied to some Rumex species other than $R$. pictus such as $R$. vesicarius (Abo El-Soud et al., 2011; El-Shafey et al., 2016 and Sayed et al., 2017), the hybrid sorrel Rumex tianschanicus $\mathrm{x}$ Rumex patientia (Ślesak et al., 2014), R cyprius (Al Khateeb et al., 2017) and $R$. nepalensis (Bhattacharyya et al., 2017). However, to our knowledge, there have been no previous reports investigating the in vitro culture of $R$. pictus.

This work studied the effect of growth regulators on micropropagation of $R$. pictus from shoot apex explant. Effect of growth regulators on the production of $R$. pictus callus and accumulation of its flavonoids was also investigated.

\section{Materials and Methods}

\section{Plant material and seed germination}

Rumex pictus Forssk seeds were collected from the Mediterranean coastal region, Alexandria, Egypt in April 2011 and the plant species was identified according to Bolous (1999). Seeds were surface sterilized using $70 \%$ ethanol for 30 sec followed by $40 \%$ commercial bleach $(5 \%$ $\mathrm{NaOCl}$ ) for $15 \mathrm{~min}$. The seeds were rinsed three times in sterile distilled water and germinated on MS medium (Murashige \& Skoog, 1962) supplemented with $8 \mathrm{~g} \mathrm{~L}^{-1}$ agar. Cold stratification was applied to the cultured seeds by incubating at $4^{\circ} \mathrm{C}$ for 4 days to induce germination. After radical emergence, cultured seeds were transferred to growth chamber and incubated at $25 \pm 2^{\circ} \mathrm{C}$ under $(16 / 8 \mathrm{~h})$ light/dark photoperiod using white cool fluorescent light $\left(100 \mu \mathrm{mol} \mathrm{m} \mathrm{m}^{-2} \mathrm{~s}^{-1}\right)$.

\section{Shoot proliferation and multiplication}

Shoot apices (4-5mm in length) were excised from 30 days-old seedlings and transferred to a baby food jar containing $20 \mathrm{ml}$ of medium. Various media were investigated for shoot induction; each was prepared by supplementing MS medium with $30 \mathrm{~g} \mathrm{~L}^{-1}$ sucrose and growth regulators (BAP, KIN and TDZ, either alone or in combination with IBA; Table 1), while MS growth regulatorsfree medium was used as control. The $\mathrm{pH}$ of the medium was adjusted at 5.8 and $8 \mathrm{~g} \mathrm{~L}^{-1}$ agar were added prior to autoclaving for $20 \mathrm{~min}$ at $121^{\circ} \mathrm{C}$ and $15 \mathrm{psi}$ pressure. The cultures were incubated at $25 \pm 2^{\circ} \mathrm{C}$ under $(16 / 8 \mathrm{~h}) \mathrm{light} /$ dark photoperiod. Explants were sub-cultured once after 4 weeks.

\section{In vitro root formation and acclimatization}

Shoots of $3-4 \mathrm{~cm}$ length were separated and transferred to MS media (full-strength or halfstrength) supplemented with $20 \mathrm{~g} \mathrm{~L}^{-1}$ sucrose. Growth regulators were supplemented as $1 \mathrm{mg}$ $\mathrm{L}^{-1}$ IAA, 1 and $2 \mathrm{mg} \mathrm{L}^{-1}$ of IBA and NAA, individually. Media were solidified by $2.5 \mathrm{~g} \mathrm{~L}^{-1}$ phytagel (Duchefa, Haarlem, The Netherlands), where roots were not induced on media solidified with agar. After 3 weeks of root induction, the plants with well developed roots were washed gently under running tap water and treated with fungicide $\left(1 \mathrm{mg} \mathrm{L}^{-1}\right.$ Metalaxyl $^{\mathrm{TM}}$, the national company for agrochemicals production, Egypt) solution. The plants were transferred to paper cups ( $6 \mathrm{~cm}$ diameter) containing sterile peat moss soil. The plants were covered with transparent polyethylene bags, to maintain humidity and 
allow penetration of light, and incubated in the growth chamber at $25 \pm 2^{\circ} \mathrm{C}$ under $(16 / 8 \mathrm{~h})$ light/ dark photoperiod. Plants were irrigated using halfstrength MS salts and gradually acclimatized to low humidity by making a hole on the plastic bag and increasing its size every 3 days, until establishment of the plants in the soil and formation of new leaves. After 2 weeks, the plants were uncovered and maintained in the same conditions for further 2 weeks, then transferred from the growth chamber to the laboratory and maintained under natural daylight at 19 and $28^{\circ} \mathrm{C}$ night-time and day-time temperatures.

\section{Callus induction}

Segments of cotyledonary and $1^{\text {st }}$ foliage leaves were excised from 30 days-old seedlings. The segments were cultured in baby food jars containing MS medium supplemented with $30 \mathrm{~g} \mathrm{~L}^{-1}$ sucrose, $8 \mathrm{~g} \mathrm{~L}^{-1}$ agar and various combinations of (1 and $\left.2 \mathrm{mg} \mathrm{L}^{-1}\right)$ 2,4-D, $\left(0.5,1\right.$ and $\left.2 \mathrm{mg} \mathrm{L}^{-1}\right)$ IBA, $\left(0.2,0.4,0.6,0.8\right.$ and $\left.1 \mathrm{mg} \mathrm{L}^{-1}\right)$ BAP and $0.5 \mathrm{mg} \mathrm{L}^{-1}$ KIN (Table 3 ). The jars were incubated in darkness at $25 \pm 2^{\circ} \mathrm{C}$. Callus was sub-cultured on the same medium after 3 weeks of culture. Fresh and dry weights of 6 weeks age calli were determined. The dry material was kept for assaying total flavonoid content.

\section{Assay of total flavonoid content}

Total flavonoids were extracted from callus of $R$. pictus by homogenizing $200 \mathrm{mg}$ of dry material in $20 \mathrm{ml}$ of $80 \%$ methanol. The homogenate was agitated on a rotary shaker at $100 \mathrm{rpm}$ and $25 \pm 2{ }^{\circ} \mathrm{C}$ for $24 \mathrm{~h}$ and then centrifuged at 6000rpm. Total flavonoid content was measured by the aluminum chloride colorimetric assay (Zhishen et al., 1999). An aliquot $(1 \mathrm{ml})$ of methanol extract or standard solution of quercetin $\left(0.01-0.07 \mathrm{mg} \mathrm{ml}^{-1}\right)$ was mixed with $4 \mathrm{ml}$ distilled $\mathrm{H}_{2} \mathrm{O}$ and $300 \mu \mathrm{l}$ of $5 \% \mathrm{NaNO}_{2}$. After $5 \mathrm{~min}, 300 \mu \mathrm{l}$ of $10 \% \mathrm{AlCl}_{3}$ were added. At the $6^{\text {th }}$ min, two $\mathrm{ml}$ of $1 \mathrm{M} \mathrm{NaOH}$ solution were added and the total volume was made up to $10 \mathrm{ml}$ with distilled $\mathrm{H}_{2} \mathrm{O}$. The solution was mixed well, and the absorbance was measured against the reagent blank at $510 \mathrm{~nm}$. Total flavonoid content was expressed as mg quercetin equivalents $\mathrm{g}^{-1}$ dry weight.

\section{Experiment design and statistical analysis}

All experiments were of completely randomized design and repeated twice. Each treatment (media variants) consisted of 5 replicates per treatment, where each replicate consisted of a baby food jar containing three explants. Data presented here are means \pm SE. One-way analysis of variance (ANOVA) was applied using SPSS V16 statistical program; the mean values were compared with Duncan's new multiple range tests at $5 \%$ significance level.

\section{$\underline{\text { Results and Discussion }}$}

\section{Shoot proliferation and multiplication}

Both percentage of shoot induction and number of shoots per explant varied due to using different combinations of growth regulators. Control(Growth regulators-free) medium did not induce any shoots. Percentage of shoot induction on media with $2 \mathrm{mg}$ $\mathrm{L}^{-1} \mathrm{KIN}+0.5 \mathrm{mg} \mathrm{L}^{-1} \mathrm{IBA}, 2 \mathrm{mg} \mathrm{L}^{-1} \mathrm{BAP}$ and $2 \mathrm{mg} \mathrm{L}^{-1}$ $\mathrm{BAP}+0.2 \mathrm{mg} \mathrm{L}^{-1}$ IBA reached $70-72 \%$, while the highest percentage of shoot induction was achieved on media supplemented with $2 \mathrm{mg} \mathrm{L}^{-1} \mathrm{TDZ}(80 \%)$. BAP supplemented into MS medium mostly induced more shoots per explant in comparison to the other cytokinins, KIN and TDZ, (Table 1 and Fig. $1 \mathrm{~A}$ ). The highest number of shoots per explant (12.6) was induced by $2 \mathrm{mg} \mathrm{L}^{-1} \mathrm{BAP}$ and it was associated with high percentage of shoot induction (70\%). Our results support those found by Al Khateeb et al. (2017), who reported that BAP induced the best results in shoot multiplication from shoot apex of $R$. cyprius when compared with TDZ and KIN. In contrast, Polygonum hydropiper exhibited a preferential multiple shoot induction from shoot tip on KIN over BAP (Hasan \& Sikdar, 2010). Effectiveness of BAP to induce multiple shoots was also reported on a variety of plants such as $R$. vesicarius, Cassia alata and Rheum emodi (Abo El-Soud et al., 2011; Ahmed et al., 2017 and Tabin et al., 2017). Superiority of BAP for shoot induction may be due to the ability of plant tissue to metabolize BAP more readily than other synthetic growth regulators (Kalia et al., 2007). However, increasing the level of BAP in the media to $3 \mathrm{mg} \mathrm{L}^{-1}$ caused a significant decline in the number of shoots per explant, indicating that the need to optimize the concentrations of cytokinin was critical in shoot multiplication.

Addition of IBA to the media had variable effects on shoot formation from shoot tips of $R$. pictus. It affected the response of explants to the various cytokinins used in the current investigation. Adding $0.2 \mathrm{mg} \mathrm{L}^{-1}$ IBA to $2 \mathrm{mg} \mathrm{L}^{-1} \mathrm{KIN}$ increased the number of shoots to nearly two-fold of that induced by $2 \mathrm{mg} \mathrm{L}^{-1} \mathrm{KIN}$ alone. Increasing the level of IBA to $0.5 \mathrm{mg} \mathrm{L}^{-1}$ lowered that enhancement to one and a half. On the other hand, culturing 
shoot tips on media supplemented with $2 \mathrm{mg}$ $\mathrm{L}^{-1} \mathrm{TDZ}$ or $2 \mathrm{mg} \mathrm{L}^{-1} \mathrm{BAP}$ in combination with $0.2 \mathrm{mg} \mathrm{L}^{-1}$ IBA decreased the percentage of shoot induction and the number of the induced shoots below those recorded with TDZ or BAP alone. The effect of addition of auxins to cytokinins in the regeneration media was diversely reported in the previous investigations. It was reported that inclusion of low concentration of auxins along with cytokinin enhanced shoot multiplication and induced higher number of shoots/explant as compared with cytokinin alone (Swain et al., 2016 and Ahmed et al., 2017). While, Kalia et al. (2007) found that adding NAA to BAP in the medium had a deleterious effect on shoot bud formation. In the present study, the obtained results indicated that the effect of IBA added to the micropropagation medium depends on the type and concentration of the cytokinin used in the growth regulators combination, suggesting that interaction between IBA and the utilized cytokinin exists.

TDZ is considered to be one of the most active PGRs for in vitro propagation system in a wide variety of plants (Guo et al., 2011). However, $R$. pictus shoots cultured on $2 \mathrm{mg}$ $\mathrm{L}^{-1}$ (Fig. $1 \mathrm{~B}$ ) showed thick broad leaves that were wrinkled, curled and brittle all indicating symptoms of hyperhydricity (Dewir et al., 2014). The abnormal plant growth associated with high TDZ concentrations was demonstrated (Banerjee et al., 2004). Kadota \& Nimii (2003) suggested that synthetic phenylurea derivatives (CPPU and TDZ) produce more hyperhydric shoots than with adenine derivatives (BAP and KIN).
In vitro root formation and acclimatization

It was reported that concentration of basal salts in medium has an important influence on root induction and quality (Shekhawat et al., 2015 and Kumari et al., 2016). R. pictus microshoots did not form roots when cultured on full strength MS media. While, half-strength MS media supplemented with NAA or IBA successfully induced roots (Table 2). Roots appeared after 3 weeks, and the ability of root formation was maximum (highest percentage of root induction; $40 \%$, maximum number of roots; 3 and maximum root length; $3 \mathrm{~cm}$ ) with either $2 \mathrm{mg}$ $\mathrm{L}^{-1}$ NAA or $1 \mathrm{mg} \mathrm{L}^{-1}$ IBA(Fig. $1 \mathrm{C}$ ). The promoting effects of reducing the salt level of medium on root induction were reviewed in several plant species (Dewir et al., 2016 and Kumari et al., 2016). Incorporation of growth regulators to the rooting media was necessary for root induction. However, IAA induced no roots from $R$. pictus shoots, even when applied with half-strength MS media (Table 2 ), indicating that root induction may be influenced also by the suitability of the exogenously added growth regulator. The superiority of IBA as effective auxin for inducing in vitro rooting over IAA and NAA was previously pointed out (Moharami et al., 2014; Swain et al., 2016 and Al Khateeb et al., 2017). IBA was reported to be the most successful auxin in root formation in several plant species (Thomas, 2007; Shekhawat et al., 2015 and Dewir et al., 2016), however an increase of IBA level (up to $2 \mathrm{mg} \mathrm{L}^{-1}$ ) decreased the percentage of root induction, root number and root length of $R$. pictus (Table 2). Similarly, Husain et al. (2007) observed that increased IBA concentration led to reduction of rooting ability of Pterocarpus marsupium along with callus formation.

TABLE 1. Effect of various combinations of growth regulators on shoot proliferation and multiplication of Rumex pictus using shoot apex after four weeks of culture.

\begin{tabular}{lcc}
\hline $\begin{array}{l}\text { Growth regulators } \\
\left(\mathbf{m g ~ L}^{-1}\right)\end{array}$ & $\begin{array}{c}\text { Shoot induction } \\
(\% \text { of control) }\end{array}$ & No. of shoots/explant \\
\hline $2 \mathrm{KIN}$ & 60 & $3.60 \pm 0.33 \mathrm{a}$ \\
$2 \mathrm{KIN}+0.2 \mathrm{IBA}$ & 60 & $7.00 \pm 1.00 \mathrm{bc}$ \\
$2 \mathrm{KIN}+0.5 \mathrm{IBA}$ & 70 & $5.30 \pm 0.60 \mathrm{ab}$ \\
$3 \mathrm{KIN}$ & 50 & $6.70 \pm 0.6 \mathrm{abc}$ \\
$2 \mathrm{BAP}$ & 70 & $12.6 \pm 1.60 \mathrm{~d}$ \\
$2 \mathrm{BAP}+0.2 \mathrm{IBA}$ & 72 & $8.80 \pm 1.10 \mathrm{c}$ \\
$3 \mathrm{BAP}$ & 50 & $4.00 \pm 1.00 \mathrm{ab}$ \\
$3 \mathrm{BAP}+0.2 \mathrm{IBA}$ & 60 & $4.00 \pm 1.00 \mathrm{ab}$ \\
$2 \mathrm{TDZ}$ & 80 & $5.40 \pm 0.51 \mathrm{ab}$ \\
$2 \mathrm{TDZ}+0.2 \mathrm{IBA}$ & 60 & $5.30 \pm 0.33 \mathrm{ab}$ \\
$3 \mathrm{TDZ}$ & 60 & $8.60 \pm 0.88 \mathrm{c}$ \\
\hline
\end{tabular}

Values followed by the same letters are not significantly different $(\mathrm{P} \leq 0.05)$. 


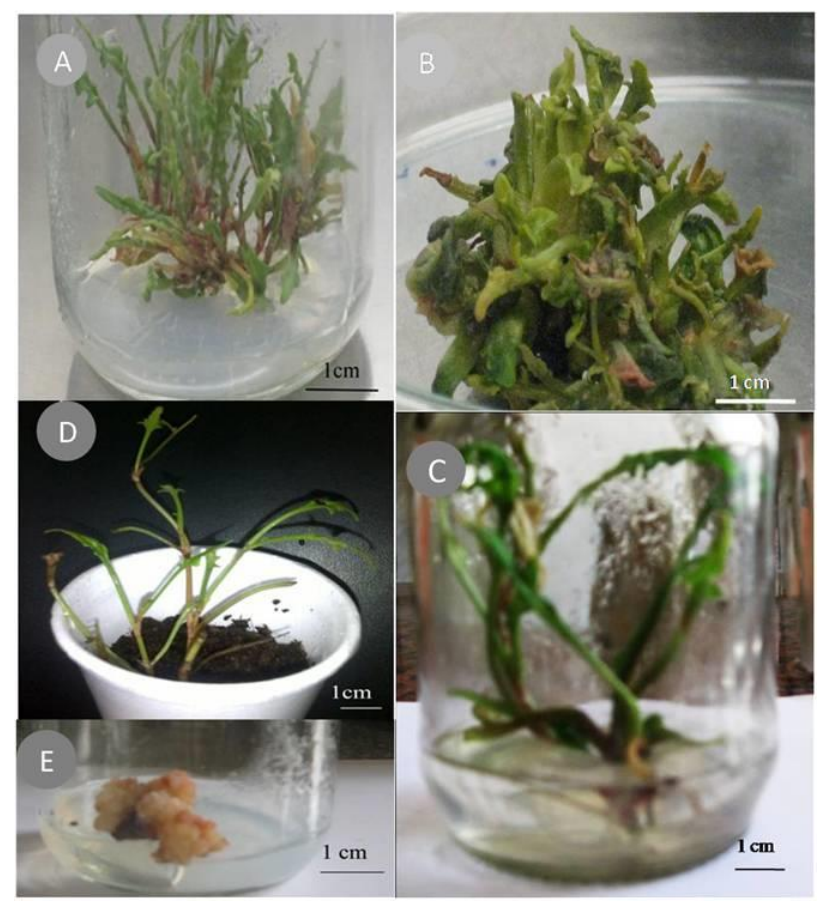

Fig. 1. Micropropagation and callus formation of Rumex pictus; A: Multiple shoots obtained from shoot tip explant cultured on MS medium supplemented with $2 \mathrm{mg} \mathrm{L}^{-1}$ BAP for four weeks, B: Hyperhydricity observed on MS medium supplemented with $3 \mathrm{mg} \mathrm{L}^{-1}$ TDZ, $C$ : Roots induced on half-strength MS medium supplemented with $1 \mathrm{mg} \mathrm{L}^{-1}$ IBA, D: Acclimatized plant and E: Three weeks old callus induced on MS media supplemented with $1 \mathrm{mg} \mathrm{L}^{-1}$ 2,4-D and $0.4 \mathrm{mg} \mathrm{L}^{-1}$ BAP using foliage leaf explant.

TABLE 2. Effect of NAA and IBA on in vitro root formation of Rumex pictus cultured for six weeks on halfstrength MS.

\begin{tabular}{lcccc}
\hline $\begin{array}{l}\text { Conc. of auxins }\left(\mathrm{mg} \mathrm{L}^{-1}\right) \\
\text { NAA }\end{array}$ & IBA & $\begin{array}{c}\text { Root induction } \\
(\%)\end{array}$ & No. of roots & $\begin{array}{c}\text { Root length } \\
(\mathbf{c m})\end{array}$ \\
\hline 0 & 0 & 0 & 0 & 0 \\
1 & 0 & 40 & 1 & 1.5 \\
2 & 0 & 40 & 3 & 3 \\
0 & 1 & 40 & 3 & 3 \\
0 & 2 & 20 & 1 & 0.5 \\
\hline
\end{tabular}

Plants with well developed roots were acclimatized by transferring to sterile peat moss soil, covered with transparent polyethylene bags, to maintain humidity, and kept in the growth chamber. During acclimatization, the plantlets were gradually transferred to regular environment by the help of irrigation with halfstrength MS salts and gradual exposure to low humidity. Such acclimatized plantlets showed better survival when they were transferred to ex vitro conditions (Fig. 1 D). The plants scored $50 \%$ survival after one month of being in ex vitro conditions.
Callus induction and total flavonoid content

Callus was induced within 12-14 days of culture at the leaf margins and cut ends. The obtained calli were reddish yellow (yellow with red spots) in color, compact and globular in texture (Fig. 1 E). The results obtained from callus culture using cotyledonary leaf explants revealed that media with combination of $2,4-\mathrm{D}$ and BAP were successful in callus induction, while those included IBA combined with either BAP or KIN did not show callogenesis (Table 3 ). In contrast, $R$. vesicarius cotyledonary explants exhibited better induction and proliferation of 
callus on IBA than on 2,4-D (El-Shafey et al., 2016). Similar to our findings, MS media supplemented with 2,4-D and KIN were found to be suitable for callus induction and proliferation of buckwheat cotyledon tissue, while NAA in combination with KIN failed in inducing callus (Woo et al., 2000).

The percentage of callus induction, when cotyledonary leaves were used as explants, reached the highest value $(88.8 \%)$ at combination of $1 \mathrm{mg} \mathrm{L}^{-1}$ 2,4-D and $0.8 \mathrm{mg} \mathrm{L}^{-1} \mathrm{BAP}$ (Table 3 ). In addition, the highest callus frequency $(100 \%)$ was recorded on combination of $1 \mathrm{mg} \mathrm{L}^{-1} 2,4-\mathrm{D}$ and $0.4 \mathrm{mg} \mathrm{L}^{-1}$ BAP using foliage leaf explants (Table 3). However, in most cases, the highest callus frequency was not accompanied by the highest proliferation of callus. The various responses of callus frequency and proliferation suggest that during each stage (induction/proliferation) the plant cells have their different needs of auxins and cytokinins, and the level of auxins and cytokinins depends not only on their uptake from the extracellular source but also on their metabolism and endogenous interaction (Jiménez \& Bangerth, 2001). The effective influence of combination of 2,4-D and BAP in enhancing callus frequency and producing maximum callus biomass was also observed on Silybum marianum and Viola wittrockiana (Cimino et al., 2006 and Wang \& Bao, 2007).

TABLE 3. Effect of growth regulators on induction, fresh weight, dry weight and flavonoid content of 6 weeks age calli induced on cotyledon and foliage leaf explants of Rumex pictus.

\begin{tabular}{|c|c|c|c|c|c|c|}
\hline \multirow{2}{*}{ Explant } & \multicolumn{2}{|c|}{$\begin{array}{c}\text { Growth regulators } \\
\qquad\left(\mathbf{m g ~ L ^ { - 1 } )}\right.\end{array}$} & \multirow{2}{*}{$\begin{array}{c}\text { Callus } \\
\text { induction }(\%)\end{array}$} & \multirow{2}{*}{$\begin{array}{c}\text { Fresh weight } \\
\text { (g) }\end{array}$} & \multirow{2}{*}{$\begin{array}{l}\text { Dry weight } \\
\text { (g) }\end{array}$} & \multirow{2}{*}{$\begin{array}{l}\text { Flavonoid content } \\
\text { (mg Quercetin } \\
\text { equivalent } g^{-1} \text { dry wt) }\end{array}$} \\
\hline & 2,4-D & BAP & & & & \\
\hline \multirow{9}{*}{ Cotyledonary leaf } & 1 & 0.2 & 66.6 & $0.56 \pm 0.05 \mathrm{ab}$ & $0.035 \pm 0.004 \mathrm{a}$ & $8.2 \pm 0.18 \mathrm{e}$ \\
\hline & 1 & 0.4 & 55.5 & $1.15 \pm 0.70 \mathrm{~b}$ & $0.079 \pm 0.039 b$ & $3.6 \pm 0.15 \mathrm{a}$ \\
\hline & 1 & 0.6 & 44.4 & $0.11 \pm 0.008 \mathrm{a}$ & $0.013 \pm 0.001 \mathrm{a}$ & $4.2 \pm 0.27 \mathrm{ab}$ \\
\hline & 1 & 0.8 & 88.8 & $0.20 \pm 0.020 \mathrm{a}$ & $0.022 \pm 0.001 \mathrm{a}$ & $3.7 \pm 0.15 \mathrm{a}$ \\
\hline & 1 & 1 & 22 & $0.04 \pm 0.016 \mathrm{a}$ & $0.008 \pm 0.002 \mathrm{a}$ & $8.4 \pm 0.30 \mathrm{e}$ \\
\hline & 2 & 0.2 & 25 & $0.06 \pm 0.029 \mathrm{a}$ & $0.007 \pm 0.003 \mathrm{a}$ & $5.5 \pm 0.4 \mathrm{~cd}$ \\
\hline & 2 & 0.4 & 37.5 & $0.04 \pm 0.006 \mathrm{a}$ & $0.005 \pm 0.001 \mathrm{a}$ & $9.3 \pm 0.52 \mathrm{f}$ \\
\hline & 2 & 0.6 & 80 & $0.02 \pm 0.007 \mathrm{a}$ & $0.003 \pm 0.001 \mathrm{a}$ & $5.9 \pm 0.20 \mathrm{~d}$ \\
\hline & 2 & 0.8 & 80 & $0.07 \pm 0003 \mathrm{a}$ & $0.009 \pm 0.002 \mathrm{a}$ & $4.9 \pm 0.09 \mathrm{bc}$ \\
\hline \multirow{8}{*}{ Foliage leaf } & 1 & 0.2 & 92 & $0.45 \pm 0.038 \mathrm{c}$ & $0.031 \pm 0.001 \mathrm{a}$ & $6.1 \pm 0.28 \mathrm{c}$ \\
\hline & 1 & 0.4 & 100 & $1.09 \pm 0.024 \mathrm{~d}$ & $0.09 \pm 0.014 \mathrm{~b}$ & $5.3 \pm 0.16 \mathrm{~b}$ \\
\hline & 1 & 0.6 & 75 & $0.31 \pm 0.023 b$ & $0.027 \pm 0.002 \mathrm{a}$ & $4.7 \pm 0.04 \mathrm{ab}$ \\
\hline & 1 & 0.8 & 60 & $0.29 \pm 0.026 b$ & $0.038 \pm 0.002 \mathrm{a}$ & $4.2 \pm 0.14 \mathrm{a}$ \\
\hline & 1 & 1 & 83 & $0.15 \pm 0.005 \mathrm{a}$ & $0.014 \pm 0.002 \mathrm{a}$ & $5.0 \pm 0.17 \mathrm{~b}$ \\
\hline & 2 & 0.2 & 50 & $0.17 \pm 0.06 \mathrm{a}$ & $0.017 \pm 0.007 \mathrm{a}$ & $9.1 \pm 0.3 \mathrm{~d}$ \\
\hline & 2 & 0.4 & 40 & $0.13 \pm 0.04 \mathrm{a}$ & $0.016 \pm 0.003 a$ & $8.7 \pm 0.13 \mathrm{~d}$ \\
\hline & 2 & 0.8 & 30 & $0.10 \pm 0.06 \mathrm{a}$ & $0.010 \pm 0.006 \mathrm{a}$ & $6.2 \pm 0.35 \mathrm{c}$ \\
\hline
\end{tabular}

Values followed by the same letters are not significantly different $(\mathrm{P} \leq 0.05)$ 
The selection of proper combination of plant growth regulators was necessary to get high percentage of callus induction and high mass production. Previous studies found that callus, of other medicinal plants belong to the family Polygonaceae rather than $R$. pictus, grows better on media containing high cytokinin: auxin ratio (Liu et al., 2005; Wang et al., 2011 and Al Khateeb et al., 2017). On the other hand, the combination of $1 \mathrm{mg}$ $\mathrm{L}^{-1} 2,4-\mathrm{D}$ and $0.4 \mathrm{mg} \mathrm{L}^{-1} \mathrm{BAP}$ was mostly the best combination for callus induction and proliferation, since it significantly induced the highest callus biomass $(1.15$ and $1.09 \mathrm{~g}$ fresh wt and 0.079 and $0.09 \mathrm{~g}$ of dry wt) from both cotyledonary and foliage leaves explants of $R$. pictus, respectively (Table 3). These differences may be due to the variation among genotypes and endogenous levels of hormones. It is worth mentioning that $1^{\text {st }}$ foliage leaf explant was better than cotyledon in scoring the highest callus frequency and the highest dry mass production, emphasizing that selecting the appropriate explant source was important factor for successful callus induction and proliferation.

Flavonoids production and accumulation by plant tissue culture were reported for various medicinal plant species (Matkowski, 2008). Our results (Table 3) revealed that increasing the concentration of BAP above $0.2 \mathrm{mg} \mathrm{L}^{-1}$ in combination with $1 \mathrm{mg} \mathrm{L}^{-1}$ 2,4-D inhibited the accumulation of flavonoids in both types of cultures (cotyledonary and foliage leaves calli). Although $2 \mathrm{mg} \mathrm{L}^{-1}$ 2,4-D induced lower callus growth with all combinations of BAP, it enhanced the accumulation of flavonoids (Table 3). The highest accumulation of flavonoids (9.3 and $9.1 \mathrm{mg}$ Quercetin equivalent $\mathrm{g}^{-1} \mathrm{dry} \mathrm{wt}$ ) was recorded in callus culture (of cotyledonary and foliage leaves, respectively) supplemented with $2 \mathrm{mg} \mathrm{L}^{-1} 2,4-\mathrm{D}+$ $0.4 \mathrm{mg} \mathrm{L}^{-1}$ BAP and $2 \mathrm{mg} \mathrm{L}^{-1} 2,4-\mathrm{D}+0.2 \mathrm{mg} \mathrm{L}^{-1}$ BAP. These results indicated that the accumulation of flavonoids in $R$. pictus callus necessitates the incorporation of higher concentration of the exogenously added auxin. Similarly, Masoumian et al. (2011) reported that auxins affected flavonoids production in callus culture of Hydrocotyl bonariensis, and supplementation of media with 2,4-D at $2 \mathrm{mg} \mathrm{L}^{-1}$ gave the highest flavonoids production. Generally, it was noticed that most of the high records of flavonoid content were accompanied with lower callus induction and proliferation (Table 3), indicating that the growth of R. pictus calli and their production of flavonoids may behave antagonistically. Similar situation was found by Downey et al. (2013) and Chaabani et al. (2015), while working on callus of soybean (Glycine max L.) and Crataegus azarolus (hawthorn), respectively.

\section{Conclusion}

Our results suggested that BAP was the most suitable cytokinin for shoot multiplication on $R$. pictus shoot tip culture. It also contributed effectively in callus induction when added to 2,4-D containing media, particularly with the $1^{\text {st }}$ foliage leaf that was the best explant for callus production and proliferation. In contrast to callus growth, accumulation of flavonoids was diminished by BAP but enhanced by increasing 2,4-D in culture medium. To the best of our knowledge this is the first study evaluating the effect of growth regulators on in vitro regeneration and callus induction of the endangered medicinal plant $R$. pictus.

\section{$\underline{\text { References }}$}

Abo El-soud, I.H., Al-azab, A., Koriesh, E.M. and Atta-Alla, H.K. (2011) Micropropagation of Rumex vesicarius $\mathrm{L}$. through shoot tip culture. Catrina Journal, 6, 41-45.

Ahmed, M.R., Anis, M., Alatar, A.A. and Faisal, M. (2017) In vitro clonal propagation, evaluation of genetic fidelity using RAPD and ISSR marker in micropropagated plants of Cassia alata L.: Apotential medicinal plant. Agroforestry Systems, 91, 637-647.

Al Khateeb, W., Alu'datt, M., Al Zghoul, H., Kanaan, R., El-Oqlah, A. and Lahham, J. (2017) Enhancement of phenolic compounds production in in vitro grown Rumex cyprius Murb. Acta Physiologiae Plantarum, 39,14.

Bhattacharyya, P., Kumaria, S., Bose, B., Paul, P. and Tandon, P. (2017) Evaluation of genetic stability and analysis of phytomedicinal potential in micropropagated plants of Rumex nepalensis A medicinally important source of pharmaceutical biomolecules. Journal of Applied Research on Medicinal and Aromatic Plants, 6, 80-91.

Banerjee, S., Tripathi, J., Verma, P.C., Dwivedi, P.D., Khanuja, S.P.S. and Bagchi, G.D. (2004) Thidiazuron-induced high-frequency shoot proliferation in Cineraria maritima Linn. Current Science, 87, 1287-1290. 
Batanouny, K.H., Aboutabl, E., Shabana, M. and Soliman, F. (1999)"Wild Medicinal Plants in Egypt". With contribution of: Aboutabl, E., Shabana, M., Soliman, F. Egypt, Academy of Scientific Research and Technology and Switzerland, International Union for Conservation (IUCN).

Bolous, L. (1999) "Flora of Egypt". Vol. 1 AzollaceaeOxalidaceae. Cairo, Al Hadara Publishing.

Bota, C. and Deliu, C. (2015) Effect of plant growth regulators on the production of flavonoids by cell suspension cultures of Digitalis lanata. Farmacia, 63, 716-9.

Chaabani, G., Tabart, J., Kevers, C., Dommes, J., Khan, M.I., Zaoui, S., Chebchoub, L., Lachaa, M. and Karray-Bouraoui, N. (2015) Effects of 2,4-dichlorophenoxyacetic acid combined to 6-Benzyl aminopurine on callus induction, total phenolic and ascorbic acid production, and antioxidant activities in leaf tissue cultures of Crataegus azarolus L. var. aronia. Acta Physiologiae Plantarum, 37, 16.

Cimino, C., Cavalli, S.V., Spina, F., Natalucci, C. and Priolo, N. (2006) Callus culture for biomass production of milk thistle as a potential source of milk clotting peptidases. Electronic Journal of Biotechnology, 9, 238-240.

Dewir, Y.H., Indoliya, Y., Chakrabarty, D. and Paek, K.Y. (2014) Biochemical and physiological aspects of hyperhydricity in liquid culture system. In: "Production of Biomass and Bioactive Compounds Using Bioreactor Technology", Paek, K.Y., Murthy, H. and Zhong, J.J. (Eds.), pp. 693-703 Springer.

Dewir, Y.H., Murthy, H.N., Ammar, M.H., Alghamdi, S.S., Al-Suhaibani, N.A., Alsadon, A.A. and Paek, K.Y. (2016) In vitro rooting of leguminous plants: Difficulties, alternatives and strategies for improvement. Horticulture, Environment and Biotechnology, 57, 311-322.

Downey, P.J., Levine, L.H., Musgrave, M.E., McKeonBennett, M. and Moane, S. (2013) Effect of hypergravity and phytohormones on isoflavonoid accumulation in soybean (Glycine $\max$ L.) callus. Microgravity Science and Technology, 25, 9-15.

El-Shafey, N.M., Ahmed, E.S., Sayed, M., Hammouda, O. and Khodary, S.A. (2016) Effect of growth regulators, carbohydrates and antioxidant compounds on biomass, flavonoid accumulation and enzyme activity in callus cultures of Rumex vesicarius L. Egyptian Journal of Botany, 56, 595612.

Goyal, S., Arora, J. and Ramawat, K.G. (2014) Biotechnological approaches to medicinal plants of aravalli hills: Conservation and scientific validation of biological activities. In: "Biotechnology and Biodiversity. Sustainable Development and Biodiversity", Ahuja, M., Ramawat, K. (Eds.), pp. 203-245. Vol. 4. Springer, Cham.

Guo, B., Abbasi, B.H., Zeb, A., Xu, L. and Wei, Y. (2011) Thidiazuron: A multi-dimensional plant growth regulator. African Journal of Biotechnology, 10, 8984-9000.

Hasan, M. and Sikdar, B. (2010) In vitro propagation of Polygonum hydropiper L. from shoot tips. Plant Tissue Culture and Biotechnology, 20, 73-79.

Husain, M.K., Anis, M. and Shahzad, A. (2007) In vitro propagation of Indian Kino (Pterocarpus marsupium Roxb.) using thidiazuron. In vitro Cellular and Developmental Biology - Plant, 43, 59-64.

Jamwal, K., Bhattacharya, S. and Puri, S. (2018) Plant growth regulator mediated consequences of secondary metabolites in medicinal plants. Journal of Applied Research on Medicinal and Aromatic Plants, 9, 26-38.

Jiménez, V.M. and Bangerth, F. (2001) Endogenous hormone levels in explants and in embryogenic and non-embryogenic cultures of carrot. Physiologia Plantarum, 111, 389-395.

Ji, X.H., Wang, Y.T., Zhang, R., Wu, S.J., An, M.M., Li, M., Wang, C.Z., Chen, X.L., Zhang, Y.M. and Chen, X.S. (2015) Effect of auxin, cytokinin and nitrogen on anthocyanin biosynthesis in callus cultures of red-fleshed apple (Malus sieversii f. niedzwetzkyana). Plant Cell Tissue and Organ Culture, 120, 325-337.

Kadota, M. and Niimi, Y. (2003) Effects of cytokinin types and their concentrations on shoot proliferation and hyperhydricity in in vitro pear cultivar shoots. Plant Cell Tissue and Organ Culture, 72, 261-265.

Kalia, R.K., Arya, S., Kalia, S. and Arya, I.D. (2007) 
Plantlet regeneration from fascicular buds of seedling shoot apices of Pinus roxburghii Sarg. Biologia Plantarum, 51, 653-659.

Kumari, A., Baskaran, P. and Van Staden, J. (2016) In vitro propagation and antibacterial activity in Cotyledon orbiculata: a valuable medicinal plant. Plant Cell, Tissue and Organ Culture, 124, 97-104.

Liu, X., Zhang, W., Jin, M. and Yu, X. (2005) Effects of explants, medium formulations and light on callus induction and secondary metabolites accumulated in the calli of Polygonum cuspidatum (Polygonaceae). Acta Botanica Yunnanica, 28, 403-409.

Mahendran, G. and Narmatha, Bai V. (2014) Micropropagation, antioxidant properties and phytochemical assessment of Swertia corymbosa (Griseb.) Wight ex CB Clarke: A medicinal plant. Acta Physiologiae Plantarum, 36, 589-603.

Manole-Paunescu, A. (2014) Biotechnology for Endangered Plant Conservation. In: "Biotechnology and Biodiversity. Sustainable Development and Biodiversity", Ahuja, M., Ramawat, K. (Eds.). Vol 4. Springer, Cham.

Masoumian, M., Arbakariya, A., Syahida, A. and Maziah, M. (2011) Flavonoids production in Hydrocotyle bonariensis callus tissues. Journal of Medicinal Plants Research, 5, 564-1574.

Matkowski, A. (2008) Plant in vitro culture for the production of antioxidants: A review. Biotechnology Advances, 26, 548-560.

Moharami, L., Hosseini, B., Ravandi, E.G. and Jafari, M. (2014) Effect of plant growth regulators and explants types on in vitro direct plant regeneration of Agastache foeniculum, an important medicinal plant. In vitro Cellular and Developmental Biology - Plant, 50, 707-711.

Mossa, J.S., Al-Yahya, M.A. and Al-Meshal, I.A. (2000) "Medicinal plants of Saudi Arabia". King Saud University Press, Riyadh.

Murashige, T. and Skoog, F. (1962) A revised medium for rapid growth and bioassays with tobacco tissue cultures. Physiologia Plantarum, 15, 473-497.

Murthy, H.N., Lee, E.J. and Paek, K.Y. (2014) Production of secondary metabolites from cell and organ cultures: strategies and approaches for biomass improvement and metabolite accumulation. Plant Cell, Tissue and Organ Culture, 118, 1-16.

Rahman, M.A., Mossa, J.S., Al-Said, M.S. and AlYahya, M.A. (2004) Medicinal plant diversity in the flora of Saudi Arabia: A report on seven plant families. Fitoterapia, 75, 149-161.

Sayed, M., Khodary, S.A., Ahmed, E.S., Hammouda, O., Hassan, H.M. and El-Shafey, N.M. (2017) Elicitation of flavonoids by chitosan and salicylic acid in callus of Rumex vesicarius L. ISHS Acta Hort 1187: IX International Symposium on In vitro Culture and Horticultural Breeding. Doi.10.17660/ ActaHortic.2017.1187.18.

Shekhawat, M.S., Kannan, N., Manokari, M. and Ravindran, C.P. (2015) In vitro regeneration of shoots and ex vitro rooting of an important medicinal plant Passiflora foetida L. through nodal segment cultures. Journal of Genetic Engineering and Biotechnology, 13, 209-14.

Ślesak, H., Liszniańska, M., Popielarska-Konieczna, M., Góralski, G., Sliwinska, E. and Joachimiak, A.J, (2014) Micropropagation protocol for the hybrid sorrel Rumex tianschanicus $\times$ Rumex patientia, an energy plant. Histological, SEM and flow cytometric analyses. Industrial Crops and Products, 62, 156-165.

Swain, D., Lenka, S., Hota, T. and Rout, G.R. (2016) Micro-propagation of Hypericum gaitii Haines, an endangered medicinal plants: assessment of genetic fidelity. The Nucleus, 59, 7-13.

Tabin, S., Kamili, A.N., Gupta, R.C., Parray, J.A. and Bansal, A. (2017) In vitro culture of Rheum emodi Wall: An endangered medicinal plant of Northwestern Himalaya. Proceedings of the National Academy of Sciences, India Section B: Biological Sciences, pp.1-12.

Thomas, T.D. (2007) Pretreatment in thidiazuron improves the in vitro shoot induction from leaves in Curculigo orchioides Gaertn., an endangered medicinal plant. Acta Physiologiae Plantarum, 29, 455-461.

Wang, J. and Bao, M.Z. (2007) Plant regeneration of pansy (Viola wittrockiana) 'Caidie' via petiolederived callus. Scientia Horticulturae, 111, 266270 . 
Wang, J., Lu, Y., Wang, Q., Liu, K., Song, Y., Bi, K. (2011) An efficient callus proliferation protocol and rhaponticin accumulation of Rheum franzenbachii Munt., a medicinal plant. Journal of Plant Biochemistry and Biotechnology, 20, 252-257.

Woo, S.H., Nair, A., Adachi, T. and Campbell, C.G. (2000) Plant regeneration from cotyledon tissues of common buckwheat (Fagopyrum esculentum
Moench). In vitro Cellular and Developmental Biology - Plant, 36, 358-361

Zhishen, J., Mengcheng, T. and Jianming, W. (1999) Research on antioxidant activity of flavonoids from natural materials. Food Chemistry, 64, 555-559

تأثير منظمات النمو على الإكثار الدقيق و استحثاث الكالوس ومحتوى فلافونويدات الكالوس من نبات الحمصيص .Rumex pictus Forssk نبات طبى مهيّد بالانقر اض فلاض

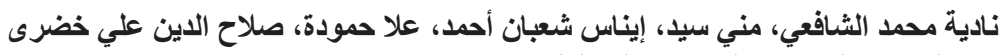

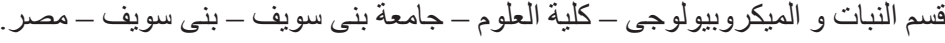

تتناول الدراسة الحالية تأثثر منظمات النمو على التكاثر الاقيق و استحثاث الكالوس ومحتوى فلافونويدات

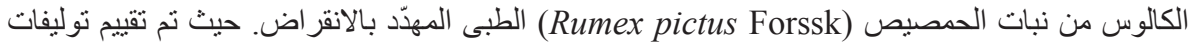

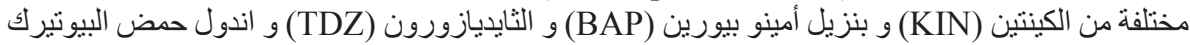

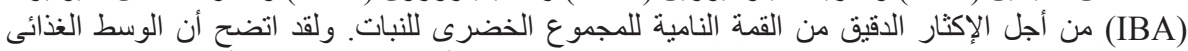

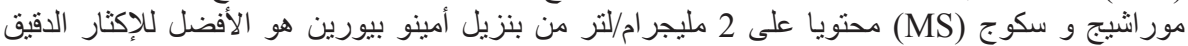

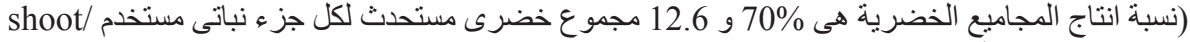

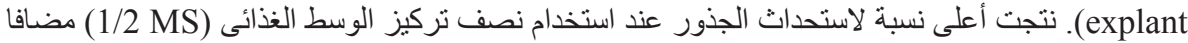

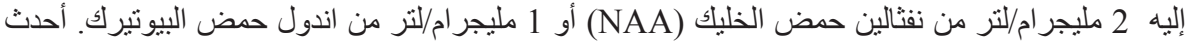

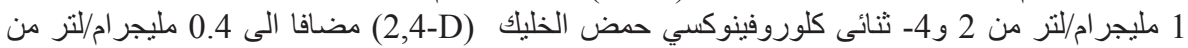

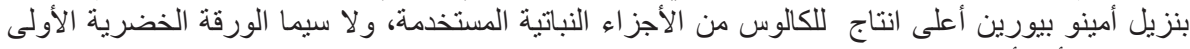

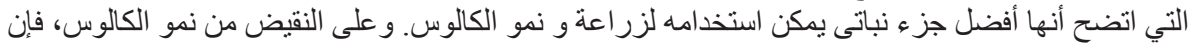

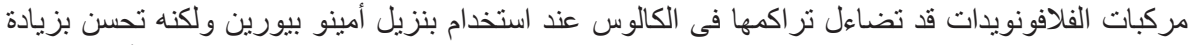

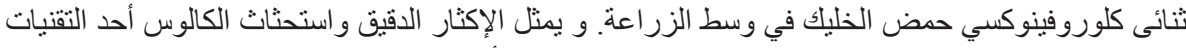

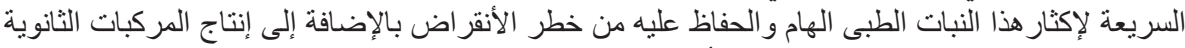

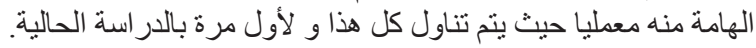

